\title{
Fatigue life estimation of clinched joints from wrought aluminium alloy with Local Strain Approach considering cold working of joining process
}

\author{
Boris Spak ${ }^{1}$, Maximilian Schlicht ${ }^{2}$, Karina Nowak ${ }^{2}$, Markus Kästner ${ }^{1}$, Pascal Froitzheim ${ }^{2}$, \\ Wilko Flügge $^{2}$, Peter Hantschke ${ }^{1}$, and Melanie Fiedler ${ }^{1}$ \\ ${ }^{1}$ Technische Universitat Dresden \\ ${ }^{2}$ Fraunhofer-Einrichtung fur Grosstrukturen in der Produktionstechnik IGP
}

October 19, 2021

\begin{abstract}
Mechanical clinching is an ef- ficient join- ing tech- nique fre- quently used in the au- tomotive industry to join sub- assemblies of the car body. Dur- ing me- chanical clinching, the ma- terial in the joint is cold worked altering the cyclic material properties and affecting the per- formance of the joint under cyclic loading. The pa- per presents an approach for fatigue life estimation of clinched joints us- ing the Local Strain Approach. Numer- ical sim- ulation is utilized to retrieve local stresses and strains in the crit- ical re- gion. Ex- perimen- tal inves- tigation is presented to vali- date the crack ini- tiation lo- cation and an assess- ment of the fa- tigue life estima- tion is car- ried out.
\end{abstract}

\section{Hosted file}

FFEMS_SpecialIssue_6thICEAF_BorisSpak_final.pdf available at https://authorea.com/ users/441816/articles/542263-fatigue-life-estimation-of-clinched-joints-from-wroughtaluminium-alloy-with-local-strain-approach-considering-cold-working-of-joining-process 